\title{
Synthesis and Single Crystal X-Ray Structure of Bis[4-oxo-3- (2-ethoxycarbonylphenyl)-3,4-dihydroquinazolin-2-yl]disulfide
}

\author{
Mehdi Rimaz ${ }^{\mathrm{a}}$, Jabbar Khalafy ${ }^{\mathrm{a}}$, Khadijeh Tavana ${ }^{\mathrm{a}}$, Katarzyna Ślepokura ${ }^{\mathrm{b}}$, Tadeusz Lis ${ }^{\mathrm{b}}$, \\ Ali Souldozic ${ }^{\text {, Amir Tofangchi Mahyarid }}{ }^{\text {, Nahid Shajarid }}{ }^{\text {, and Ali Ramazani }}{ }^{\mathrm{d}}$ \\ ${ }^{a}$ Chemistry Department, Urmia University, Urmia 57154, Urmia, Iran \\ ${ }^{\mathrm{b}}$ Faculty of Chemistry, University of Wrocław, 14 Joliot-Curie St., 50-383 Wrocław, Poland \\ c Chemistry Department, Islamic Azad University-Urmia Branch, P. O. Box 969, Urmia, Iran \\ ${ }^{\mathrm{d}}$ Chemistry Department, Zanjan University, P. O. Box 45195-313, Zanjan, Iran \\ Reprint requests to Dr. Ali Ramazani. Fax: +98 241 5283100. E-mail: aliramazani@gmail.com \\ Z. Naturforsch. 2009, 64b, 1065 - 1069; received May 22, 2009 \\ Diethyl 2,2'-thiocarbonyl-bis(azanediyl)dibenzoate was synthesized from the reaction of ethyl an- \\ thranilate with thiophosgene. Its treatment with sodium ethoxide in ethanol at room temperature gave \\ ethyl 2-(4-oxo-2-thioxo-1,2-dihydroquinazolin-3(4H)-yl) benzoate, whereas in the presence of ethyl \\ nitroacetate and under the same reaction conditions, the corresponding bis(quinazolin)disulfide was \\ formed. Its structure was confirmed by IR, ${ }^{1} \mathrm{H}$ and ${ }^{13} \mathrm{C}$ NMR spectroscopy elemental analysis and \\ single crystal X-ray structure determination.
}

Key words: Thiophosgene, Ethyl Anthranilate, Ethyl Nitroacetate, Disulfide, Single Crystal X-Ray Structure

\section{Introduction}

The reaction of $o$-substituted arylamines with thiophosgene to form isothiocyanates is well known [1,2]. However, the direct generation of $N, N^{\prime}$-disubstituted thioureas by using this reaction is not so wellknown. Herein, we report the preparation of diethyl 2,2'-thiocarbonyl-bis(azanediyl)dibenzoate (2) and its treatment with sodium ethoxide in ethanol at r.t. leading to ethyl 2-(4-oxo-2-thioxo-1,2-dihydroquinazolin-3(4H)-yl) benzoate (3), which may possess biological activity and provide an incentive for further exploration of this class of compounds as potential drug precursors [3-9]. Finally, we treated the $N, N^{\prime}$-disubstituted thiourea $\mathbf{2}$ with ethyl nitroacetate in the presence of sodium ethoxide in ethanol at $\mathrm{r}$. $\mathrm{t}$. to form bis[4-oxo-3-(2-ethoxycarbonylphenyl)-3,4-dihydroquinazolin-2-yl]disulfide (4).

\section{Results and Discussion}

The $N, N^{\prime}$-disubstituted thiourea $\mathbf{2}$ was prepared from the reaction of ethyl anthranilate (1) with thiophosgene [1,2] (Scheme 1).

Treatment of the $N, N^{\prime}$-disubstituted thiourea 2 with sodium ethoxide in ethanol at r.t. afforded the corresponding quinazoline derivative $\mathbf{3}$ in $89 \%$ yield (Scheme 2).<smiles>CCOC(=O)c1ccccc1N</smiles>

1
2

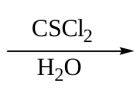

Scheme 1.<smiles>CCOC(=O)c1ccccc1NC(=S)Nc1ccccc1C(=O)OCC</smiles><smiles>CCOC(=O)c1ccccc1-n1c(=S)[nH]c2ccccc2c1=O</smiles>

3
Scheme 2 .

We observed that treatment of the thiourea 2 with ethyl nitroacetate and sodium ethoxide in ethanol under the same reaction conditions gave, surprisingly, the corresponding disulfide 4 in moderate yield (46\%, Scheme 3).

The structure of compound $\mathbf{4}$ was confirmed by IR, ${ }^{1} \mathrm{H}$ and ${ }^{13} \mathrm{C}$ NMR spectroscopy, elemental analysis and $\mathrm{X}$-ray single crystal structure determination.

\section{Description of the crystal structure of $\mathbf{4}$}

The crystals of $\mathbf{4}$ are built up from molecules, the geometry of which reveals a pseudo (non-crystallographic) two-fold axis running through the center 
到

2<smiles>CCOC(=O)c1ccccc1-n1c(SSc2nc3ccccc3c(=O)n2-c2ccccc2C(=O)OCC)nc2ccccc2c1=O</smiles>

Scheme 3.

Table 1. Crystal data and structure refinement details for $\mathbf{4}$.

Empirical formula
Formula weight, $\mathrm{g} \mathrm{mol}^{-1}$
Crystal system, space group
$a, \AA$
$b, \AA$
$c, \AA$
$\beta$, deg
$V, \AA^{3}$
$Z$
$D_{\text {calc }}, \mathrm{g} \mathrm{cm}{ }^{-3}$
$\mu$, mm
$F(000)$, e
Crystal size, mm
Crystal color and form
Data collection method
Radiation type; wavelength $\lambda, \AA$
$T, \mathrm{~K}$
$\theta$ range, deg
$h, k, l$ ranges

Measured / independent refl.

Observed refl. $[I>2 \sigma(I)]$

Refinement on

Data / parameters

$R 1 / w R 2\left[F_{\mathrm{o}}^{2} \geq 2 \sigma\left(F_{\mathrm{o}}^{2}\right)\right]^{\mathrm{a}}$

$R 1 / w R 2$ (all data) ${ }^{\mathrm{a}}$

Weighting parameter $a / b$

$\mathrm{GoF}=S^{\mathrm{b}}$

$\Delta \rho_{\max } / \Delta \rho_{\min }, \mathrm{e} \AA^{-3}$

\section{$\mathrm{C}_{34} \mathrm{H}_{26} \mathrm{~N}_{4} \mathrm{O}_{6} \mathrm{~S}_{2}$}

650.71

monoclinic, $P 2{ }_{1} / n$

12.483(4)

$18.819(5)$

$13.853(4)$

$110.77(3)$

$3042.8(15)$

4

1.420

0.229

1352

$0.24 \times 0.13 \times 0.08$

colorless block

$\omega$ scans

$\mathrm{MoK}_{\alpha} ; 0.71073$

$100(2)$

$2.68-25.50$

$-15 \leq h \leq 15,-20 \leq k \leq 22$,

$-16 \leq l \leq 14$

$24906 / 5655$

3251

$F^{2}$

5655 / 429

$0.069 / 0.157$

$0.118 / 0.189$

$0.0980 / 0.0$

1.017

$0.64 /-0.36$

${ }^{\mathrm{a}} R 1=\Sigma|| F_{\mathrm{O}}|-| F_{\mathrm{c}} \| / \Sigma\left|F_{\mathrm{o}}\right|, w R 2=\left[\Sigma w\left(F_{\mathrm{O}}{ }^{2}-{F_{\mathrm{c}}}^{2}\right)^{2} / \Sigma w\left(F_{\mathrm{O}}{ }^{2}\right)^{2}\right]^{1 / 2}$, $w=\left[\sigma^{2}\left(F_{\mathrm{o}}{ }^{2}\right)+(a P)^{2}+b P\right]^{-1}$, where $P=\left(\operatorname{Max}\left({F_{\mathrm{o}}}^{2}, 0\right)+2{F_{\mathrm{c}}}^{2}\right) / 3$;

${ }^{\mathrm{b}} \mathrm{GoF}=\left[\Sigma w\left(F_{\mathrm{o}}{ }^{2}-F_{\mathrm{c}}{ }^{2}\right)^{2} /\left(n_{\mathrm{obs}}-n_{\mathrm{param}}\right)\right]^{1 / 2}$.

of the S-S bond (Fig. 1). The S-S bond length of 2.023(2) $\AA$ is close to the average value observed in organic disulfides [10]. The summary of the experimental details is given in Table 1.

The value of the torsion angle $\mathrm{C}(11)-\mathrm{S}(1)-\mathrm{S}(2)-$ $\mathrm{C}(12)$ amounts to $91.9(2)^{\circ}$, which is very close to the average found in compounds of similar structure [10]. The values of the torsion angles S-S-C-N (Table 2) indicate that the $\mathrm{S}-\mathrm{S}$ bond lies in the plane of the respective quinazolin-4-one ring. Thus, according to the Shefter classification [11], molecule 4 exists in a socalled equatorial conformation. At the same time, the two quinazolin-4-one moieties are almost perpendicu-
Table 2. Selected interatomic distances $(\AA)$, valence and torsion angles (deg) in $\mathbf{4}$.

\begin{tabular}{lrrr}
\hline $\mathrm{S}(1)-\mathrm{S}(2)$ & $2.023(2)$ & $\mathrm{N}(12)-\mathrm{C}(92)$ & $1.414(5)$ \\
$\mathrm{S}(1)-\mathrm{C}(11)$ & $1.798(4)$ & $\mathrm{N}(21)-\mathrm{C}(11)$ & $1.286(5)$ \\
$\mathrm{S}(2)-\mathrm{C}(12)$ & $1.790(4)$ & $\mathrm{N}(21)-\mathrm{C}(31)$ & $1.411(5)$ \\
$\mathrm{N}(11)-\mathrm{C}(11)$ & $1.375(5)$ & $\mathrm{N}(22)-\mathrm{C}(12)$ & $1.280(5)$ \\
$\mathrm{N}(11)-\mathrm{C}(13)$ & $1.446(5)$ & $\mathrm{N}(22)-\mathrm{C}(32)$ & $1.398(5)$ \\
$\mathrm{N}(11)-\mathrm{C}(91)$ & $1.410(5)$ & $\mathrm{C}(81)-\mathrm{C}(91)$ & $1.458(5)$ \\
$\mathrm{N}(12)-\mathrm{C}(12)$ & $1.390(5)$ & $\mathrm{C}(82)-\mathrm{C}(92)$ & $1.460(6)$ \\
$\mathrm{N}(12)-\mathrm{C}(14)$ & $1.455(5)$ & & \\
$\mathrm{C}(11)-\mathrm{S}(1)-\mathrm{S}(2)$ & $101.4(2)$ & $\mathrm{C}(12)-\mathrm{S}(2)-\mathrm{S}(1)$ & $100.9(2)$ \\
$\mathrm{C}(11)-\mathrm{S}(1)-\mathrm{S}(2)-\mathrm{C}(12)$ & $91.9(2)$ & \\
$\mathrm{C}(13)-\mathrm{N}(11)-\mathrm{C}(11)-\mathrm{S}(1)$ & $11.5(4)$ & \\
$\mathrm{S}(2)-\mathrm{S}(1)-\mathrm{C}(11)-\mathrm{N}(21)$ & $2.1(3)$ & \\
$\mathrm{C}(14)-\mathrm{N}(12)-\mathrm{C}(12)-\mathrm{S}(2)$ & $9.9(4)$ & \\
$\mathrm{S}(1)-\mathrm{S}(2)-\mathrm{C}(12)-\mathrm{N}(22)$ & $5.3(3)$ & \\
$\mathrm{C}(91)-\mathrm{N}(11)-\mathrm{C}(13)-\mathrm{C}(23)$ & $90.3(4)$ & \\
$\mathrm{C}(83)-\mathrm{O}(23)-\mathrm{C}(73)-\mathrm{C}(63)$ & $170.7(4)$ & \\
$\mathrm{C}(92)-\mathrm{N}(12)-\mathrm{C}(14)-\mathrm{C}(24)$ & $98.9(4)$ & \\
$\mathrm{C}(84)-\mathrm{O}(24)-\mathrm{C}(74)-\mathrm{C}(64)$ & $-179.8(4)$ & \\
$\mathrm{C}(53)-\mathrm{C}(63)-\mathrm{C}(73)-\mathrm{O}(13)$ & $18.7(6)$ & \\
$\mathrm{C}(73)-\mathrm{O}(23)-\mathrm{C}(83)-\mathrm{C}(93)$ & $-158.8(8)$ & \\
$\mathrm{C}(54)-\mathrm{C}(64)-\mathrm{C}(74)-\mathrm{O}(14)$ & $15.6(6)$ & \\
$\mathrm{C}(74)-\mathrm{O}(24)-\mathrm{C}(84)-\mathrm{C}(94)$ & $-166.7(5)$ & \\
\hline
\end{tabular}

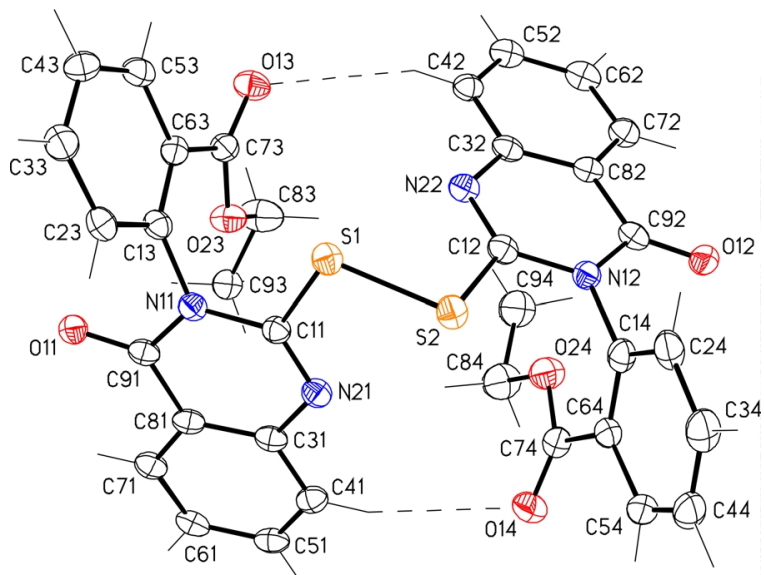

Fig. 1. The molecular structure of compound $\mathbf{4}$ showing the atom numbering scheme. Only one position (with higher occupation factor) for each of the disordered methyl groups is shown. The intramolecular $\mathrm{C}-\mathrm{H} \cdots \mathrm{O}$ contacts forming two $S(13)$ motifs are shown with dashed lines. Displacement ellipsoids are drawn at the $30 \%$ probability level. 


\begin{tabular}{lcccc}
\hline $\mathrm{D}-\mathrm{H} \cdots \mathrm{A}$ & $\mathrm{D}-\mathrm{H}(\AA)$ & $\mathrm{H} \cdots \mathrm{A}(\AA)$ & $\mathrm{D} \cdots \mathrm{A}(\AA)$ & $\mathrm{D}-\mathrm{H} \cdots \mathrm{A}(\operatorname{deg})$ \\
\hline $\mathrm{C}(41)-\mathrm{H}(41) \cdots \mathrm{O}(14)$ & 0.95 & 2.63 & $3.552(6)$ & 164 \\
$\mathrm{C}(51)-\mathrm{H}(51) \cdots \mathrm{O}(11)^{i}$ & 0.95 & 2.53 & $3.281(5)$ & 136 \\
$\mathrm{C}(42)-\mathrm{H}(42) \cdots \mathrm{O}(13)$ & 0.95 & 2.66 & $3.540(5)$ & 154 \\
$\mathrm{C}(33)-\mathrm{H}(33) \cdots \mathrm{O}(12)^{i i}$ & 0.95 & 2.63 & $3.462(5)$ & 146 \\
$\mathrm{C}(83)-\mathrm{H}(83 B) \cdots \mathrm{O}(14)^{i i i}$ & 0.99 & 2.71 & $3.501(7)$ & 137 \\
\hline
\end{tabular}

Table 3. Geometry of proposed hydrogen bonds for 4 ( $\mathrm{A}, \operatorname{deg}$ ).

Symmetry codes: (i) $x-1 / 2,-y+3 / 2, z-1 / 2$; (ii) $x, y, z+1$; (iii) $x+1 / 2,-y+3 / 2, z+1 / 2$.

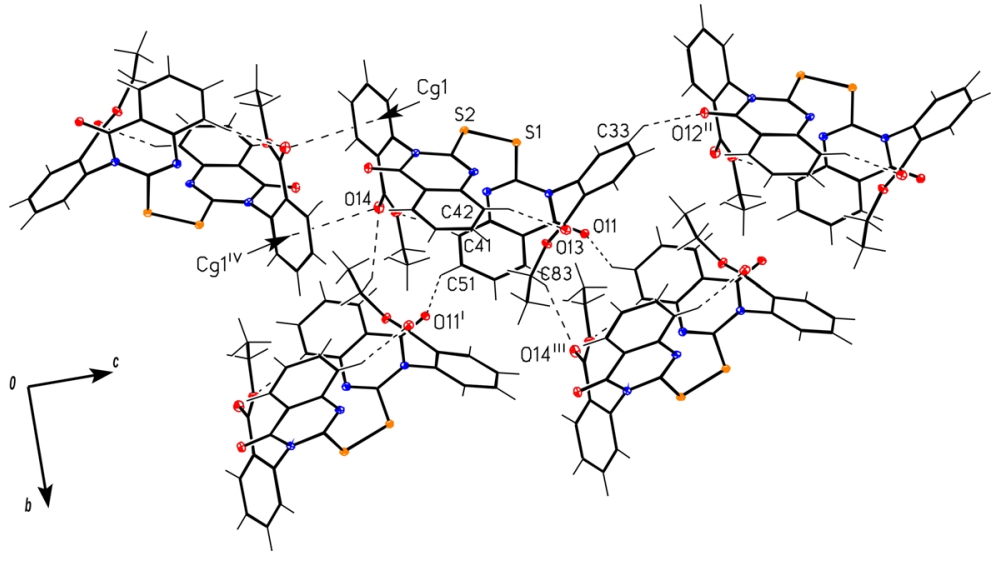

Fig. 2. The arrangement of the molecules in the crystal lattice of $\mathbf{4}$ (viewed down the $a$ axis). Intermolecular $\mathrm{C}-\mathrm{H} \cdots \mathrm{O}$ and $\mathrm{C}=\mathrm{O} \cdots \pi$ contacts are shown with dashed lines. Symmetry codes are given in Table 3.

lar to each other, with the dihedral angle between the least-squares planes defined by the condensed rings amounting to $87.5(1)^{\circ}$. The quinazolin-4-one rings are also almost perpendicular to the respective, directly bonded, phenyl rings.

The overall conformation of the molecule 4 is stabilized by two intramolecular $\mathrm{C}-\mathrm{H} \cdots \mathrm{O}$ contacts (Table 3 ) linking the two halves of the molecule and resulting in two $S(13)$ motifs, as shown in Fig. 1. Atom $\mathrm{O}(14)$ is additionally involved in a weak intermolecular $\mathrm{C}-\mathrm{H}$... O interaction, as well as in a close centrosymmetric $\mathrm{C}=\mathrm{O} \cdots \pi$ contact $\left[\mathrm{C}(74)=\mathrm{O}(14) \cdots C g(1)^{i v}\right.$; symmetry code $(i v)$ : $-x,-y+1,-z ; C g(1)$ is the centroid of the phenyl $\mathrm{C}(14)-\mathrm{C}(64)$ ring; geometrical parameters: $\mathrm{O} \cdots C \mathrm{Cg} 3.784(4) \AA$, perpendicular $\mathrm{O} \cdots C g 3.698 \AA, \mathrm{C} \cdots C g$ 3.865(4) $\AA, \mathrm{C}=\mathrm{O} \cdots C g$ angle $84.7(2)^{\circ}$ ]. Two other carbonyl oxygen atoms, $\mathrm{O}(11)$ and $\mathrm{O}(12)$, act as acceptors of yet another set of intermolecular hydrogen contacts (Table 3). All that gives rise to a three-dimensional architecture of the crystal lattice of compound 4, shown in Fig. 2.

\section{Conclusions}

In summary, we have synthesized a new derivative of 4-oxo-2-thioxo-1,2,3,4-tetrahydroquinazoline 3 and the related bis(quinazoline)-disulfide 4 under two convenient reaction conditions. The single crystal X-ray analysis of compound 4 reveals that the $\mathrm{S}-\mathrm{S}$ bond lies in the planes of the quinazolin-4-one rings, but with almost perpendicular mutual orientation of these two ring planes.

\section{Experimental Section}

\section{General procedures}

Freshly distilled solvents were used throughout, and anhydrous solvents were dried according to Perrin and Armarego [12]. ${ }^{1} \mathrm{H}(300 \mathrm{MHz})$ and ${ }^{13} \mathrm{C}(75.5 \mathrm{MHz})$ NMR measurements were carried out on a Bruker 300 spectrometer in $\mathrm{CDCl}_{3}$ with tetramethylsilane as internal standard. Infrared spectra were recorded on a Thermonicolet (Nexus 670) FTinfrared spectrometer, using sodium chloride cells, measured as Nujol mulls or films. Melting points were determined on a Philip Harris C4954718 apparatus and are uncorrected. Elemental analysis was performed on a Carlo Erba 1106 C, H, $\mathrm{N}$ analyzer.

\section{Diethyl 2,2'-thiocarbonyl-bis(azanediyl)dibenzoate (2)}

In a $250 \mathrm{~mL}$ round-bottomed flask were placed water $(50 \mathrm{~mL})$ and thiophosgene $(2.53 \mathrm{~g}, 1.75 \mathrm{~mL}, 22 \mathrm{mmol})$. To the vigorously stirred reaction mixture was added slowly ethyl anthranilate (1) $(3.63 \mathrm{~g}, 22 \mathrm{mmol}$, diluted in ethyl acetate), during about half an hour. The dark-brown oil was separated, washed with $10 \%$ hydrochloric acid $(2 \mathrm{~mL})$, and placed in a two-necked flask for steam distillation. Product 2 passed over with water as a pale-yellow oil. The product was extracted with dichloromethane $(30 \mathrm{~mL})$ and dried 
over sodium sulfate. Removal of the solvent gave a yellow oil which was recrystallized from $n$-hexane to give $\mathbf{2}$ as pale-yellow crystals (not suitable for an X-ray experiment). Yield: 1.23 g (30\%); m. p. $86-87{ }^{\circ} \mathrm{C} .-{ }^{1} \mathrm{H} \mathrm{NMR}\left(\mathrm{CDCl}_{3}\right)$ : $\delta(\mathrm{ppm})=1.39(\mathrm{t}, J=7.2 \mathrm{~Hz}, 6 \mathrm{H}), 4.36(\mathrm{q}, J=6.9 \mathrm{~Hz}, 4 \mathrm{H})$, $7.18\left(\mathrm{td}, J_{1}=8.7 \mathrm{~Hz}, J_{2}=1.5 \mathrm{~Hz}, 2 \mathrm{H}, \mathrm{Ar}\right), 7.57\left(\mathrm{td}, J_{1}=\right.$ $\left.8.7 \mathrm{~Hz}, J_{2}=1.5 \mathrm{~Hz}, 2 \mathrm{H}, \mathrm{Ar}\right), 8.05\left(\mathrm{dd}, J_{1}=7.8 \mathrm{~Hz}, J_{2}=\right.$ $1.5 \mathrm{~Hz}, 2 \mathrm{H}, \mathrm{Ar}$ ), 8.50 (bd, $J=8.4 \mathrm{~Hz}, 2 \mathrm{H}, \mathrm{Ar}$ ), 11.05 (s, exchanged by $\mathrm{D}_{2} \mathrm{O}$ addition, $\left.2 \mathrm{H}, \mathrm{NH}\right) .-{ }^{13} \mathrm{C} \mathrm{NMR}\left(\mathrm{CDCl}_{3}\right)$ : $\delta(\mathrm{ppm})=14.17,61.59,118.64,123.10,123.73,131.08$, 133.30, 140.51, 167.49, 178.82. - FT IR: $v=3236,2976$, $1685,1605,1580,1509,1447,1364,1301,1251,1168$, 1089, 1004, 927, 765, $730 \mathrm{~cm}^{-1}$. - Anal. for $\mathrm{C}_{19} \mathrm{H}_{20} \mathrm{~N}_{2} \mathrm{O}_{4} \mathrm{~S}$ : calcd. C 62.27, H 5.41, N 7.52; found C 62.38, H 5.50, N 7.45.

\section{Ethyl 2-(4-oxo-2-thioxo-1,2-dihydroquinazolin-3(4H)-yl) benzoate (3)}

In a $25 \mathrm{~mL}$ round-bottomed flask, absolute ethanol $(10 \mathrm{~mL})$ was reacted with sodium $(0.015 \mathrm{~g}, 0.65 \mathrm{mmol})$, and after cooling to r.t. compound $2(0.12 \mathrm{~g}, 0.322 \mathrm{mmol})$ was added. The reaction mixture was stirred at r.t. for 15 min. Then the mixture was acidified with $10 \%$ acetic acid $(2 \mathrm{~mL})$, and the white precipitate was collected by vacuum filtration. The white solid was recrystallized from absolute ethanol to give the desired product 3 as white needles. Yield: $93 \mathrm{mg}(89 \%)$; m.p. $183-185{ }^{\circ} \mathrm{C}$. $-{ }^{1} \mathrm{H}$ NMR $\left(\mathrm{CDCl}_{3}\right): \delta(\mathrm{ppm})=1.14(\mathrm{t}, J=6.9 \mathrm{~Hz}, 3 \mathrm{H}), 4.19(\mathrm{q}, J=$ $6.9 \mathrm{~Hz}, 2 \mathrm{H}), 7.15(\mathrm{~d}, 8.1 \mathrm{~Hz}, 1 \mathrm{H}), 7.34(\mathrm{~d}, J=9.3 \mathrm{~Hz}$, $2 \mathrm{H}), 7.60\left(\mathrm{td}, J_{1}=7.5 \mathrm{~Hz}, J_{2}=1.2 \mathrm{~Hz}, 1 \mathrm{H}\right), 7.64(\mathrm{td}$, $\left.J_{1}=7.5 \mathrm{~Hz}, J_{2}=1.2 \mathrm{~Hz}, 1 \mathrm{H}\right), 7.74\left(\mathrm{td}, J_{1}=7.5 \mathrm{~Hz}, J_{2}=\right.$ $1.2 \mathrm{~Hz}, 1 \mathrm{H}), 8.17(\mathrm{~d}, J=7.8 \mathrm{~Hz}, 1 \mathrm{H}), 8.27(\mathrm{~d}, J=7.8 \mathrm{~Hz}$, $1 \mathrm{H}), 10.89$ (s, exchanged by $\mathrm{D}_{2} \mathrm{O}$ addition, $\left.1 \mathrm{H}, \mathrm{NH}\right) .-{ }^{13} \mathrm{C}$ $\mathrm{NMR}\left(\mathrm{CDCl}_{3}\right): \delta(\mathrm{ppm})=13.85,61.26,114.94,116.45$, $125.05,127.78,128.72,129.32,130.29,132.17,133.75$, 135.69, 138.91, 138.97, 160.26, 164.29, 176.44. - FT IR: $v=3245,3136,2976,1717,1665,1620,1529,1487,1406$, 1263, 1199, $757 \mathrm{~cm}^{-1}$. - Anal. for $\mathrm{C}_{17} \mathrm{H}_{14} \mathrm{~N}_{2} \mathrm{O}_{3} \mathrm{~S}$ : calcd. C 62.56, H 4.32, N 8.58; found C 62.67, H 4.40, N 8.45.

\section{Bis[4-oxo-3-(2-ethoxycarbonylphenyl)-3,4-dihydro- quinazolin-2-yl]disulfide (4)}

In a $25 \mathrm{~mL}$ round-bottomed flask, absolute ethanol $(3 \mathrm{~mL})$ was reacted with sodium $(0.092 \mathrm{~g}, 4 \mathrm{mmol})$, and after cooling to r.t. ethyl nitroacetate $(0.665 \mathrm{~g}, 5 \mathrm{mmol})$ was added. The reaction mixture was stirred at r.t. for $15 \mathrm{~min}$. Compound 2 (1.86 g, $5 \mathrm{mmol}$ ) was added, and the stirring was continued for further $24 \mathrm{~h}$, during which a yellowish-white precipitate was formed. The precipitate was extracted with chloroform and dried over sodium sulfate. Removal of the solvent gave 4 as pale-yellow needles. Yield: $0.41 \mathrm{~g}$, $(46 \%)$; m. p. $189-$ $192{ }^{\circ} \mathrm{C} .-{ }^{1} \mathrm{H} \mathrm{NMR}\left(\mathrm{CDCl}_{3}\right): \delta(\mathrm{ppm})=1.14(\mathrm{t}, J=6.9 \mathrm{~Hz}$, $6 \mathrm{H}), 4.18(\mathrm{q}, J=6.9 \mathrm{~Hz}, 2 \mathrm{H}), 4.20(\mathrm{q}, J=6.9 \mathrm{~Hz}, 2 \mathrm{H}), 7.18$ (d, $J=8.1 \mathrm{~Hz}, 2 \mathrm{H}, \mathrm{Ar}), 7.32(\mathrm{~d}, J=7.8 \mathrm{~Hz}, 2 \mathrm{H}, \mathrm{Ar}), 7.35$ (t, $J=6.9 \mathrm{~Hz}, 2 \mathrm{H}, \mathrm{Ar}), 7.61\left(\mathrm{td}, J_{1}=7.5 \mathrm{~Hz}, J_{2}=0.9 \mathrm{~Hz}\right.$, $2 \mathrm{H}, \mathrm{Ar}), 7.64\left(\mathrm{td}, J_{1}=9.6 \mathrm{~Hz}, J_{2}=1.5 \mathrm{~Hz}, 2 \mathrm{H}, \mathrm{Ar}\right), 7.75$ $\left(\mathrm{td}, J_{1}=7.8 \mathrm{~Hz}, J_{2}=1.2 \mathrm{~Hz}, 2 \mathrm{H}, \mathrm{Ar}\right), 8.18\left(\mathrm{dd}, J_{1}=7.8 \mathrm{~Hz}\right.$, $\left.J_{2}=1.2 \mathrm{~Hz}, 2 \mathrm{H}, \mathrm{Ar}\right), 8.28\left(\mathrm{dd}, J_{1}=7.8 \mathrm{~Hz}, J_{2}=1.2 \mathrm{~Hz}, 2 \mathrm{H}\right.$, Ar). $-{ }^{13} \mathrm{C} \mathrm{NMR}\left(\mathrm{CDCl}_{3}\right): \delta(\mathrm{ppm})=13.85,61.29,115.07$, $116.45,125.07,127.83,128.68,129.34,130.34,132.19$, $133.77,135.69,138.97,139.00,160.35,164.32,176.38$. FT IR: $v=3218,3173,3072,3035,2976,1719,1663,1620$, 1525, 1487, 1451, 1406, 1365, 1199, 1127, 1078, 1039, 988, $890,800,756,715 \mathrm{~cm}^{-1}$. - Anal. for $\mathrm{C}_{34} \mathrm{H}_{26} \mathrm{~N}_{4} \mathrm{O}_{6} \mathrm{~S}_{2}$ : calcd. C 62.76, H 4.03, N 8.61; found C 62.84, H 4.11, N 8.50.

\section{Crystal structure determination of $\mathbf{4}$}

The crystallographic measurement for crystal 4 was performed on a $\kappa$-geometry Kuma KM4CCD automated fourcircle diffractometer with graphite-monochromatized $\mathrm{Mo} K_{\alpha}$ radiation. The data were collected at 100(2) K using the Oxford Cryosystems cooler. The data were corrected for Lorentz and polarization effects. A summary of the conditions for the data collection and the structure refinement parameters are given in Table 1. Data collection, cell refinement, and data reduction and analysis were carried out with the KM4CCD software CRYSALIS CCD and CRYSALIS RED, respectively [13]. The structure was solved by $\mathrm{Di}-$ rect Methods using SHELXS-97 [14] and refined by fullmatrix least-squares techniques using SHELXL-97 [14] with anisotropic displacement parameters for non- $\mathrm{H}$ atoms, except for disordered low-occupied methyl C930 and C940 atoms. Both ethyl groups are disordered and were refined with methylene $\mathrm{C}$ atoms in the same positions and with the same anisotropic displacement parameters (constrains were applied with EXYZ and EADP instructions). Methyl $\mathrm{C}$ atoms were refined in two distinct positions. The ethyl groups were refined with s.o.f. $=0.76(3) / 0.24(3)$ for $\mathrm{C} 83 / \mathrm{C} 830-\mathrm{C} 93 /$ C930 and 0.71(2)/0.29(2) for C84/C840-C94/C940. Most of the $\mathrm{H}$ atoms were found in difference Fourier maps, and in the final refinement cycles all hydrogens were treated as riding atoms, with $\mathrm{C}-\mathrm{H}$ distances of $0.95-0.99 \AA$, and with $U_{\text {iso }}$ values of $1.5 U_{\text {eq }}(\mathrm{C})$ for $\mathrm{CH}_{3}$ groups, and $1.2 U_{\text {eq }}(\mathrm{C})$ for $\mathrm{CH}_{2}$ and $\mathrm{CH}$ groups. All figures were made using the program XP [15].

CCDC 731854 contains the supplementary crystallographic data for this paper. These data can be obtained free of charge from The Cambridge Crystallographic Data Centre via www.ccdc.cam.ac.uk/data_request/cif. 
[1] F. B. Dains, R. Q. Brewester, C. P. Olander, Org. Synth., Coll. 1941, 1, 447.

[2] G. M. Dyson, Org. Synth., Coll. 1941, 1, 165.

[3] J. Vandenberk, L. Kennis, V. der Heertum, U. S. Patent 4522 945, 1985.

[4] P.Z. Tan, J. Soares, J. Seibyl, R. M. Baldwin, C. van Dyck, M. Al-Tikriti, X. Fu, D. S. Charney, R. D. Innis, J. Labelled Compd. Radiopharm. 1999, 42, 66-68.

[5] T. Michinori, O. Takashi, S. Seiji, U. Seiichi, H. Shunichi, Jpn. Patent 62258369, 1986.

[6] T. Sohda, H. Makino, A. Boba, Eur. Patent EP 0567107, 2001.

[7] H. Eto, T. Koda, Y. Ogawa, T. Katori, Jpn. Patent 60075488, 1983.

[8] R. A. LeMahieu, M. Carson, A. F. Welton, H. W. Baruth, B. Yaremko, J. Med. Chem. 1983, 26, 107-110.
[9] M. Carson, R. A. LeMahieu, J. W. Tilley, Eur. Patent EP 142057, 1984.

[10] Cambridge Structural Database (CSD). See: F.H. Allen, Acta Crystallogr. 2002, B58, 380-388.

[11] E. Shefter, J. Chem. Soc. B 1970, $903-906$.

[12] D. D. Perrin, W. L. F. Armarego, Purification of Laboratory Chemicals, Pergamon Press, Oxford, 1988, pp. $20-35$.

[13] CRys Alis CCD, CRYs Alis Red (ver. 1.171), Oxford Diffraction Poland, 2006.

[14] G. M. Sheldrick, Acta Crystallogr. 2008, A64, 112 122.

[15] XP (ver. 5.1), Interactive molecular graphics, Bruker Analytical X-ray Instruments Inc., Madison, Wiscon$\sin$ (USA) 1998. 